\title{
Owner's Responsibilities of Vehicles Used as Illegal Public Transport When Traffic Accidents Happened
}

\author{
Hesti Kristi Wahyudi*) and Sri Kusriyah**) \\ ${ }^{*}$ Student Master of Law, Faculty of Law, Universitas Islam Sultan Agung \\ Semarang, E-mail: hestykw@gmail.com \\ ${ }^{* *}$ Faculty of Law Universitas Islam Sultan Agung
}

\begin{abstract}
The research objectives to be taken in the intended research plan are as follows: To know and analyzecriminal law construction for owners of vehicles used as public transportation or commercialized. To find out and analyzeconstruction of criminal law is the responsibility of owners of vehicles commercialized as public transportation. To find out and analyzesolution to the problem of responsibility of vehicle owners who commercialize their vehicles illegally when a traffic accident occurs on the highway. The method used by researchers isjuridical sociological approach to law and the specification in this research is including analytical descriptive. Based on the results of that research Construction based on criminal law Act No. 22 of 2009 concerningTraffic and road transportArticle 308 is a sanction for every person driving a public motorized vehicle not equipped with a license to carry out person transportation/not having a route. The construction of liability criminal law is based on Act No. 22 of 2009 concerningTraffic and road transport Article 315 states that when a criminal offense is committed by a Public Transportation Company, the criminal liability is imposed on the Public Transportation Company by adding a maximum fine of 3 (three) times the fines specified in each article and also subject to additional penalties in the form of temporary suspension or revocation transport operating license for the vehicle used.The obstacles: there are no articles in the Road Traffic and Transportation Act No. 22 of 2009 that can be used to ensnare vehicle owners. The solution is to hope that this article will exist so that in the future it can create a deterrent effect for vehicle owners so that they do not go around operating their vehicle without being equipped with existing terms and conditions in accordance with the law and in the future it is also expected to prevent the occurrence of traffic accident victims in large numbers.

Keywords: Liability; Illegal Public Transport; Traffic Accidents.
\end{abstract}

\section{Introduction}

Road traffic and transportation have a strategic role in supporting national development and integration as part of efforts to advance public welfare as mandated by the 1945 Constitution of the Republic of Indonesia (hereinafter referred to as the 1945 Constitution of the Republic of Indonesia). As part of the national transportation system, road traffic and transportation must develop their potential and role in realizing security, welfare, traffic order and road transportation in the framework of supporting economic development and the development of science and technology, regional autonomy, and accountability for State administration. ${ }^{1}$

\footnotetext{
${ }^{1}$ Second Aline, Explanation of Act No. 22 Year 2009 concerning Road Traffic and Transportation
} 
In the framework of administering road traffic and transportation, Act No. 22 of 2009 concerning Road Traffic and Transportation (hereinafter abbreviated to Law on Road Traffic and Transportation) has been established which regulates several provisions including those related to the purpose of managing traffic and road transportation, division of authority between government agencies and regional governments, regulating matters of a technical nature to road traffic and road transportation operations, road traffic and transportation infrastructure, as well as efforts to develop, prevent, regulate and enforce laws. The Law on LLAJ states that there are three objectives for the implementation of Road Traffic and Transportation, namely: a. the realization of Traffic and Road Transportation services that are safe, secure, orderly, smooth, and integrated with other modes of transportation to encourage the national economy, promote public welfare, strengthen national unity and integrity, and be able to uphold national dignity; $b$. the realization of traffic ethics and national culture; and c. the realization of law enforcement and legal certainty for the community. ${ }^{2}$

In its implementation, the Law on LLAJ has not been able to accommodate developments, problems and legal needs in society. Changes that occur in society in the context of road traffic and transportation occur so rapidly that they go beyond the existing Law on LLAJ. These changes should be followed by changes in existing legal rules so that conditions in society can be accommodated by law. In legal science, this concept is known as formal legal politics which aims to "make the ius constitutum developed from the old legal systems into ius constituendum or law for the future". ${ }^{3}$

Transportation is a common thing in many places. All regions in Indonesia have a means of transportation that connects one place to another. The importance of transportation for the people of Indonesia is due to several factors, among others, the geographical condition of Indonesia which consists of thousands of small and large islands, waters which consist of most of the sea, rivers and lakes which allow transportation to be carried out by land, water and air to reach the entire territory. Indonesia. ${ }^{4}$

The occurrence of traffic accidents, is not only contained in Article 240 of the Road Traffic and Transportation Law but is also regulated in the Law on Traffic and Road Transportation in Chapter XIV, the third part regarding obligations and responsibilities and paragraph 1 regarding the obligations and responsibilities of drivers, owners of motorized vehicles, and/or transportation companies, in Article 234 it is explained that drivers, motorized vehicle owners and/or public transport companies are responsible for losses suffered by passengers and/or goods owners and/or third parties due to the driver's negligence.

Settlement of traffic accidents found on the streets at certain times and is considered a routine activity, because it is more of an administrative service. In the field of vehicles, apart from that, the discipline of road users is still very low. If physically there are no

\footnotetext{
${ }^{2}$ Article 3 of Act No. 22 of 2009 concerning Road Traffic and Transportation.

${ }^{3}$ Abdul Latif and Hasbi Ali. (2016). Politik Hukum. Jakarta: Sinar Grafika. p. 6-7.

${ }^{4}$ Abdulkadir, Muhammad. (1998). Hukum Pengangkutan Niaga. Bandung: Citra Aditya Bakti. p. 7.
} 
members of the Police/Traffic Police there is a tendency to commit violations by violating traffic signs. ${ }^{5}$

The research objectives to be taken in the intended research plan are as follows: To know and analyzecriminal law construction for owners of vehicles used as public transportation or commercialized. To find out and analyzeconstruction of criminal law is the responsibility of owners of vehicles commercialized as public transportation. To find out and analyzesolution to the problem of responsibility of vehicle owners who commercialize their vehicles illegally when a traffic accident occurs on the highway.

\section{Research methods}

Through a sociological juridical approach, it means that an approach is carried out directly in the field. This research is a descriptive legal research.And secondary data obtained from literature study. The data were analyzed qualitatively.

\section{Results and Discussion}

\subsection{Criminal Law Construction for Vehicle Owners Used As Public Or Commercial Transport}

Law exists in every human society anywhere on this earth. However primitive and how modern a society must have laws. Therefore, the existence (existence) of law is universal. Law cannot be separated from society, but in fact has a reciprocal relationship. $^{6}$

The history of traffic in Indonesia cannot be separated from the development of world automotive technology which originated from the discovery of engines with petroleum fuels. During the era of the Dutch East Indies government which then ruled Indonesia, it began to bring 4-wheeled and 2-wheeled vehicles to Indonesia, causing traffic activity. $^{7}$

Traffic in Law No. 22 of 2009 is defined as the movement of vehicles and people in the road traffic space, while what is meant by road traffic space is infrastructure designated for moving vehicles, people, and/or goods in the form of roads and supporting facilities. The government has a goal of realizing safe, secure, fast, smooth, orderly and orderly road traffic and transportation, convenient and efficient through traffic management and traffic engineering. The procedure for traffic on the road is regulated by statutory regulations regarding traffic direction, priority to use roads, traffic lanes, traffic lanes and control of flow at intersections. ${ }^{8}$

\footnotetext{
5 Akhmad Khisni,Rudiana Eka Pramana Putra, Traffic Accident Analysis in Prosses Evidence in Traffic Accidents Based on Act No. 22 of 2009, Journal of Legal Sovereignty Vol 1, No 4 (2018): December 2018 Sultan Agung Islamic University 10.30659 / jdh.1.4.951 - 956

${ }^{6}$ Teguh Prasetyo and Abdul Halim Barkatullah. (2009). Ilmu Hukum Dan Filsafat Hukum. Yogyakarta: Pustaka Pelajar. p. 38

7 M Farid Amirullah, Standard Operating Crime Investigation Traffic Accidents Journal of Legal Sovereignty Vol 1, No 3 (2018): September 2018 Universitas Islam Sultan Agung 10.30659 / jdh.1.3.837 842

${ }^{8}$ http://id.wikipedia.org/wiki/Lalu_lintas accessed on 25 November 2020 at 16:08
} 
Whereas in the case of then that is the vehicle. The microbus elf is a private property, not a public transport company or managed by a company with legal status. And this article is only an administrative violation, not a crime or crime.

Criminal law construction for owners of vehicles used as public transportation or commercialized based on Act No. 22 of 2009 concerningTraffic and road transportArticle 308 is a sanction for every person driving a public motorized vehicle not equipped with a license to carry out person transportation/not having a route. This article applies to every driver, not to the owner of the vehicle and this Article is only a violation, not a crime.

\subsection{Construction of Criminal Law Liability of Owners of Vehicles Commercialized as Public Transportation}

A traffic accident according to Act No. 22 Year 2009 Article 1 paragraph (24) is an incident on the road which is unexpected and accidentally involves a vehicle with or without other road users which results in human casualties and/or property. Traffic is the movement of vehicles and people in road traffic spaces. Accidents can cause mild to severe impacts, both material and non-material, human victims and property loss. ${ }^{9}$

The existence of an accident is a driver's fault factor in the absence of a sense of caution and negligence in driving the vehicle. It can be said that the vehicle driver's mistake which results in death can be said that the person has committed a criminal act. $^{10}$. It is understandable why the carrier (operator) is responsible for the passengers. Because the control over the transportation equipment rests with the operator both in operating, maintenance, including the safety of the transportation equipment. The operator is primarily responsible for doing this. The passenger position is passive. All you have to do is pay the freight, get on the vehicle and the rest will leave your fate to the operator to deliver it to its destination. ${ }^{11}$

However, in public transportation, it is not only the drivers who are blamed for causing traffic accidents. Entrepreneurs or public transport companies that employ other people to become drivers or crew of their vehicles are also obliged to be responsible for any loss of traffic accidents caused by the actions of the driver or vehicle crew. Regarding the responsibility of public transportation companies, it is stated in Article 191 of Act No. 22 Year 2009 concerning Road Traffic and Transportation which reads "Public Transportation Companies are responsible for losses caused by all actions of people employed in transportation management activities". So it cannot be denied that public transportation companies have responsibility for all losses due to vehicle crews,

\footnotetext{
${ }^{9}$ Umi Enggarsasi and Nur Khalimatus Sa'diyah, Study of the Factors Causing Traffic Accidents in Efforts to Improve Traffic Accident Prevention, Journal of Perspective, Vol. 22 No. 3, 2017. P. 230

${ }^{10}$ Agio V. Sangki. 2012. "Criminal Liability of Vehicle Drivers That Result in Death in a Traffic Accident". Lex Crimen. Vol. 1, No. 1.

11 Kun Wahyu Wardana. (2009). Hukum Asuransi Proteksi Kecelakaan Angkutan. Bandung: Mandar Maju. p. 20-21
} 
Criminal liability if a perpetrator has to commit a criminal act; able to be responsible; deliberate or negligent, and the absence of excuses, ${ }^{12}$ discussion related to elements of criminal liability in cases of driver negligence that cause traffic accidents are as follows:

- Must have committed a criminal act; Criminal liability can only occur if a person has previously committed a criminal act. Moeljatno said that "it is impossible for a person to be held responsible (sentenced to a criminal) if he does not commit a criminal act he has committed a criminal act." ${ }^{13}$ Criminal liability will only occur if someone has previously committed a criminal act.

- Be able to be responsible; From the point of view of the ability to be responsible, only someone who is able to take responsibility can be accountable for the speech. It is said that a person is able to be responsible, if in general his mental state is not disturbed and his soul is able to realize the essence of his actions, he can determine his will for the action, whether to be carried out or not and, can know the negligence of the action. ${ }^{14}$

- Deliberately or negligently; In every case of traffic accidents that occur on the highway, of course, have legal consequences for the driver of the vehicle. The legal provisions governing deadly accidents that result in injury or death of a person are generally the KUHP (Criminal Code) and are specifically regulated in Law (UU) No. 22 of 2009 concerning Traffic. ${ }^{15}$

Construction of the criminal law on the liability of owners of vehicles commercialized as public transportation based onAct No. 22 of 2009 concerningTraffic and road transport Article 315 states that when a criminal offense is committed by a Public Transportation Company, the criminal responsibility is imposed on the Public Transportation Company and/or its management by adding a maximum fine of 3 (three) times the fines specified in each article and also subject to additional penalties in the form of temporary freezing or revocation of transportation operation permit for used vehicles.

\subsection{Solution to the Constraints and Responsibilities of Vehicle Owners Who Commercialize Their Vehicles Illegally When a Traffic Accident Occurs on the Highway}

The fatality rate of a traffic accident is measured by the result of the accident the more victims who die as a result of the accident, the higher the fatality of the traffic accident. This fatality rate is measured by certain coefficients. Likewise in taking steps to reduce the number of accidents, the fatality rate of an accident must be reduced, of

\footnotetext{
${ }^{12}$ Saleh, Roslan. (1982). Perbuatan Pidana dan Pertanggungjawaban Pidana. Jakarta: Aksara Baru. p. 7576

${ }^{13}$ Moelyatno. (1987). Asas-Asas Hukum Pidana. Jakarta: Bina Aksara. p. 19.

${ }^{14}$ EY Kanter and SR Sianturi. (2002). Asas-Asas Hukum Pidana di Indonesia. Jakarta: Storia Grafika. p. 249

${ }^{15}$ Muhammad Dani Hamzah, Penegakan Hukum Pada Kasus Tindak Pidana Kecelakaan Lalu Lintas Yang Menyebabkan Hilangnya Nyawa Orang, Journal of Daulat Hukum Vol. 1. No. March 1, 2018 ISSN: 2614560X
} 
course by paying attention to and prioritizing the safety factor in driving by complying with applicable regulations. ${ }^{16}$

Public transportation is a means of transportation that is used by the community together by paying tariffs. Public transportation is the opposite of 'private vehicle'. Public transportation plays a role in meeting human needs for increased movement or mobility, to move from one place to another which is close, medium or far away. Public transport also plays a role in traffic control, fuel or energy savings, as well as regional planning \& development. ${ }^{17}$

Obstacles faced by investigators when conducting an investigation that leads to the owner the vehicle is the absence of Articles in the Law on Traffic and Road Transportation Number 22 of 2009 which can be used to ensnare the owner of the Microbus Elf vehicle as a suspect or person who has a role or person who can be held criminally responsible in the occurrence of a traffic accident the cross, given the large number o f casualties and large material losses.

Traffic offenders still do not have a deterrent effect because until now there are still many traffic violations, lack of personnel to carry out their duties, and insufficient number of officers. There are still people who don't know about traffic rules. ${ }^{18}$

Solution to the constraints of the responsibility of vehicle owners who commercialize their vehicles illegally when a traffic accident occurs on the highway, namely We hope that this article will have a deterrent effect on vehicle owners so that they do not operate their vehicle arbitrarily without being equipped with the existing terms and conditions in accordance with the law and in the future it is also hoped that it can prevent traffic accident victims in large numbers. The fact is that there are still many vehicle owners who operate their vehicles like travel vehicles even though the fact is that they are not equipped with a valid license and there is no legality.

\section{Closing}

Based on the description above, it can be concluded that Criminal law construction for owners of vehicles used as public transportation or commercialized based on Act No. 22 of 2009 concerningTraffic and road transportArticle 308 is a sanction for every person driving a public motorized vehicle not equipped with a license to carry out person transportation/not having a route. Criminal law construction is the responsibility of owners of vehicles commercialized as public transportation based on Act No. 22 of 2009 concerningTraffic and road transport Article 315 states that when a criminal offense is committed by a Public Transportation Company, the criminal responsibility is imposed on the Public Transportation Company and/or its management by adding a maximum fine of 3 (three) times the fines specified in each article and also subject to additional penalties in the form of temporary freezing or

\footnotetext{
${ }^{16}$ Dadik Purnomo, Jawade Hafidz, The Role of Sat Then Rembang Police in Suppressing Traffic Accidents, Journal of Daulat Hukum Vol. 1. No. March 1, 2018 ISSN: 2614-560X

${ }^{17}$ Warpani, Suwardjoko. (2000). Merencanakan System Perangkutan. Bandung: ITB. p. 34

18 Anis Mashdurohatun,Bobby Anugrah Rachman,Achmad Sulchan, Traffic Effectiveness by Law Enforcement Community Through Which are Ticketed Traffic Law in Police of Pekalongan, Journal of Legal Sovereignty Vol 2, No 1 (2019): March 2019 Sultan Agung Islamic University, (10.30659 / jdh.2.1.115 - 122)
} 
revocation of transportation operation permit for used vehicles. Solution to the constraints of the responsibility of vehicle owners who commercialize their vehicles illegally when a traffic accident occurs on the highway.The obstacles: there are no articles in the Road Traffic and Transportation Act No. 22 of 2009 that can be used to ensnare the owner of the vehicle as a suspect or person who has a role or person who can be held criminally responsible in the traffic accident, given the number of heavy casualties and huge material losses. The solution is to hope that this article will exist so that in the future it can create a deterrent effect for vehicle owners so that they do not go around operating their vehicle without being equipped with existing terms and conditions in accordance with the law and in the future it is also expected to prevent the occurrence of traffic accident victims in large numbers.

There is awareness for owners of private vehicles that are used as public transportation that do not have a route permit because their actions have caused losses to the Government and the Community, Owners of private vehicles should comply with all applicable procedures or provisions before making their vehicles. As a public transportation, the Department of Transportation, Communication and Information Technology must always socialize and apply the existence of Law of the Republic of Indonesia Number 22 of 2009 concerning Road Traffic and Transportation to owners of private vehicles that are used as public transportation without a route permit.

\section{References}

\section{Journals}

[1] Agio V. Sangki. 2012. "Criminal Liability of Vehicle Drivers That Result in Death in a Traffic Accident". Lex Crimen. Vol. 1, No. 1.

[2] Akhmad Khisni,Rudiana Eka Pramana Putra, Traffic Accident Analysis in Prosses Evidence in Traffic Accidents Based on Act No. 22 of 2009, Journal of Legal Sovereignty Vol 1, No 4 (2018): December 2018 Universitas Islam Sultan Agung 10.30659/jdh.1.4.951 - 956

[3] Anis Mashdurohatun,Bobby Anugrah Rachman,Achmad Sulchan, Traffic Effectiveness by Law Enforcement Community Through Which are Ticketed Traffic Law in Police of Pekalongan, Journal of Legal Sovereignty Vol 2, No 1 (2019): March 2019 Sultan Agung Islamic University, (10.30659/jdh.2.1.115 - 122)

[4] Dadik Purnomo, Jawade Hafidz, The Role of Sat Then Rembang Police in Suppressing Traffic Accidents, Journal of Daulat Hukum Vol. 1. No. March 1, 2018 ISSN: 2614-560X

[5] M Farid Amirullah, Standard Operating Crime Investigation Traffic Accidents Journal of Legal Sovereignty Vol 1, No 3 (2018): September 2018 Sultan Agung Islamic University 10.30659/jdh.1.3.837 - 842

[6] Muhammad Dani Hamzah, Law Enforcement in the Criminal Case of a Traffic Accident That Causes the Loss of Human Lives, Journal of Daulat Hukum Vol. 1. No. March 1, 2018 ISSN: 2614-560X 
[7] Umi Enggarsasi and Nur Khalimatus Sa'diyah, Study of the Factors Causing Traffic Accidents in Efforts to Improve Traffic Accident Prevention, Journal of Perspective, Vol. 22 No. 3, 2017.

\section{Books}

[1] Abdul Latif and Hasbi Ali. (2016). Politik Hukum. Jakarta: Sinar Grafika

[2] Abdulkadir, Muhammad. (1998). Hukum Pengangkutan Niaga. Bandung: Citra Aditya Bakti

[3] EY Kanter and SR Sianturi. (2002). Asas-Asas Hukum Pidana di Indonesia. Jakarta: Storia Grafika

[4] Kun Wahyu Wardana. (2009). Hukum Asuransi Proteksi Kecelakaan Angkutan. Bandung: Mandar Maju.

[5] Moelyatno. (1987). Asas-Asas Hukum Pidana. Jakarta: Bina Aksara

[6] Saleh, Roslan. (1982). Criminal Actions and Criminal Accountability. Jakarta: New Script

[7] Teguh Prasetyo and Abdul Halim Barkatullah. (2009). IImu Hukum Dan Filsafat Hukum. Yogyakarta: Pustaka Pelajar

[8] Warpani, Suwardjoko. (2000). Merencanakan System Perangkutan. Bandung: ITB

Internet

[1] http://id.wikipedia.org/wiki/Lalu_lintas accessed on 25 November 2020 at 16:08 